\title{
Some Indicators of Beech Forests Vitality in the Republic of Serbia in Period 2004-2009
}

Radovan Nevenić

Institute of forestry, Belgrade, Kneza Višeslava 3

11030 Belgrade, Serbia nevenic@eunet.rs

\section{Zoran Poduška}

Institute of forestry, Belgrade, Kneza Višeslava 3 11030 Belgrade, Serbia
Ljubinko Rakonjac

Institute of forestry, Belgrade, Kneza Višeslava 3

11030 Belgrade, Serbia
Svetlana Bilibajkić

Institute of forestry, Belgrade, Kneza Višeslava 3

11030 Belgrade, Serbia
Tomislav Stefanović

Institute of forestry, Belgrade, Kneza Višeslava 3

11030 Belgrade, Serbia

\author{
Renata Gagić Serdar \\ Institute of forestry, Belgrade, \\ Kneza Višeslava 3 \\ 11030 Belgrade, Serbia
}

Ilija Đorđević

Institute of forestry, Belgrade, Kneza Višeslava 3 11030 Belgrade, Serbia

\section{Goran Češljar}

Institute of forestry, Belgrade, Kneza Višeslava 3 11030 Belgrade, Serbia

\section{Abstract}

Background and purpose: Forests monitoring is one of the largest forest bio-monitoring systems that is carried out in order to record changes by using the most important environmental parameters. The National Focal Centre for forest monitoring in the Republic of Serbia, within the Institute of Forestry of the Republic of Serbia has been taking an active part in an international program of ICP Forest, with a view to improving its working activities and harmonizing them with other approaches to monitoring forests and forest ecosystems.

Material and methods: In order to determine forest ecosystem processes, it is necessary to carry out detailed research of ecological and socio-economic consequences of forest deterioration and to study the impacts of regional climate changes on forest communities. In the period from 2004 to 2009, observations were performed on 130 sample plots and data necessary for further analysis were collected. These plots are systematically arranged in either a $16 \times 16 \mathrm{~km}$ or a $4 \times 4 \mathrm{~km}$ grid system. The main parameters assessed on the sample plots are the degree of defoliation and discolouration as well as the extent of damage. A comparative analysis of the data obtained in this period will provide a better insight into the present state of beech forests in Serbia as well the effects of defoliation and discolouration trends.

Results and conclusion: Beech is the most common broadleaved tree species on the Level I sample plots. Its health state is the result of adverse effects of complex factors of abiotic and biotic origin (i.e. effects of both living organisms and complex natural processes within the beech forests habitats). This paper presents some indicators of beech forest vitality whose occurrence show certain regularity and which can be interpreted as a trend. The annual values of the health state elements and the fluctuations of these parameters from year to year present important indicators of vitality of beech forests in Serbia.

Key words: health state, pollution, crown, beech

\section{INTRODUCTION}

The Level I forest monitoring has been continuously carried out in accordance with the ICP Programme and Manual on the established sample plots - study areas - on the territory of the Republic of Serbia since 2002 [1]. The main objective of ICP Forests is monitoring the effects of anthropogenic and natural stress factors (in particular air pollution) on the present condition and development of forest ecosystems [2]. The Level I forest condition monitoring of this programme mainly refers to observation and assessment of tree crown defoliation and discolouration on certain lots of the sample plots. The main parameters to be assessed are defoliation (percentage of leaf or needle loss), discolouration and damage visible on the trees, caused by many biotic (fungi, insect pests etc.) and abiotic factors [3].

Since the system of forest condition monitoring was integrated into the state forestry environment, under the coordination of the Forest Directorate and 
National Focal Centre (NFC) for the forest condition monitoring of the Institute of Forestry, several relevant institutions together with their associates have taken part in the International Co-operative Programme on Assessment and Monitoring of Air Pollution Effects on Forests operating under the UNECE Convention on Long-range Transboundary Air Pollution (CLRTAP'). The data are collected on more than 6000 sample plots established in more than 40 participating countries, which make the Level I network of forest condition monitoring, systemically arranged in $16 \times 16 \mathrm{~km}$ and $4 \times 4 \mathrm{~km}$ grid systems across Europe [4].

Forests monitoring is one of the largest forest biomonitoring systems that is carried out in order to record changes by using the most important environmental parameters. The collected data can be used to determine both the spatial and the temporal trends of the forest condition as well as the tree species and the condition of their crown in different regions. A wider context can include the correlation between the crown condition data and the relevant sample plot data or the external data on natural and anthropogenic stress factors, which can tell us a lot about the mutual relationship between the stress factors and forest vitality.

Beech is the most widely distributed tree species in the hilly and mountainous regions of our country (particularly large beech forests occur in South East and East Serbia). It grows individually or within forest ecosystems at the altitude range from 100 to $2100 \mathrm{~m}$. Pure beech forests (both high and coppice) account for $28 \%$ of the growing stock in Serbia, and $16.4 \%$ when mixed with other species.

\section{MATERIAL AND METHODS}

In the period from 2004 to 2009 , observations and assessment of tree crowns were carried out on 130 sample plots which were established on the territory of the Republic of Serbia, in the grid system of either $16 \times 16 \mathrm{~km}$ or $4 \times 4 \mathrm{~km}$. The number of trees per species slightly varied from year to year because some trees were felled and replaced with new ones, while some sample plots were clear-felled, so that in 2009 the total number sample plots was 122 . In the final year of the research, the assessment of the tree crown defoliation and discolouration as well as the damage caused by biotic and abiotic factors was carried out on 2765 trees. Beech was the most common species with 841 trees (Table 1).

The researchers from the Institute of Forestry regularly perform field checks of the sample plots within the forest management units in the presence of other forestry experts - forest inspectors, forest engineers

1 CLRTAP Convention on Long-Range Transboundary Air Pollution
TABLE 1

Percentage of broadleaved trees on sample plots in 2009

\begin{tabular}{|l|c|c|}
\hline Species of broadleaves & Number & $\%$ \\
\hline Fagus moesiaca & 841 & 34 \\
\hline Quercus cerris & 505 & 21 \\
\hline Quercus frainetto & 362 & 15 \\
\hline Quercus petraea & 168 & 7 \\
\hline Other species & 446 & 18 \\
\hline Total Broadleaves & 2434 & 100 \\
\hline
\end{tabular}

TABLE 2

Classes of defoliation according to ICP Forests classification

\begin{tabular}{|c|c|c|}
\hline Class & Degree of defoliation & Needle / leaf loss (\%) \\
\hline 0 & none & $0-10$ \\
\hline 1 & slight (warning) & $>10-25$ \\
\hline 2 & moderate & $>25-60$ \\
\hline 3 & severe & $>60-100$ \\
\hline 4 & dead & 100 \\
\hline
\end{tabular}

TABLE 3

Classes of discolouration according to ICP Forests classification

\begin{tabular}{|c|c|c|}
\hline $\begin{array}{c}\text { Classes od } \\
\text { discolouration } \\
- \text { chlorosis }\end{array}$ & $\begin{array}{c}\text { Degree of } \\
\text { discolouration }\end{array}$ & $\begin{array}{c}\text { Percentage od } \\
\text { leaf chlorosis } \\
(\%)\end{array}$ \\
\hline 0 & none & $0-10$ \\
\hline 1 & slight (warning) & $>10-25$ \\
\hline 2 & moderate & $>25-60$ \\
\hline 3 & severe & $>60-100$ \\
\hline 4 & dead & 100 \\
\hline
\end{tabular}

and technicians responsible for particular districts in which sample plots have been established. Within the frame of the national and transnational research (Level I), the crown condition is expressed by the classes of defoliation, discolouration and combined classes of damage. Defoliation is estimated in $5 \%$ steps and grouped into 5 classes of uneven scope width (Table 2). Discolouration is an important diagnostic indicator of the crown condition and can be assessed by the classes presented in Table 3. The combined classes of damage are shown in Table 4. Discolouration is an important diagnostic indicator of the crown condition and can be estimated according to the classes stated in the Table 3. The combined assessment of the defoliation and discolouration of the leaves/ needles is shown in the Table 4. 


\section{TABLE 4}

Combined assessment of damage according to ICP Forests classification

\begin{tabular}{|c|c|c|c|c|}
\hline Class of defoliation - dying & \multicolumn{4}{|c|}{ Class of discolouration-colour loss, chlorosis } \\
\hline \multirow{2}{*}{0} & 0 & 1 & 2 & \multicolumn{2}{c|}{3} \\
\cline { 2 - 5 } & & Resulting class of damage & 2 \\
\cline { 2 - 5 } & 0 & 0 & 1 & 2 \\
\hline 1 & 0 & 1 & 2 & 3 \\
\hline 2 & 1 & 2 & 3 & 3 \\
\hline 3 & 2 & 3 & 3 & \\
\hline
\end{tabular}

\section{RESULTS}

Although six years is a relatively short period for a complete statistical data processing in the form of a comparative analysis, the processed data and the values obtained for the classes of defoliation and discolouration can be used to make some conclusions. Therefore, any conclusions made should be interpreted only as conditionally reliable trend.

Deterioration of beech forests, either acute or chronic, has been a problem in a great number of European countries, including Serbia, but also on the North American continent. In our country, a significant deterioration of beech forests was recorded for the first time in 1956-1957 in the eastern parts of the country. There are numerous abiotic and biotic factors which cause forest deterioration. The most critical are certainly anthropogenic impacts (excessive tree cutting and exploitation disturb the natural balance in the forest ecosystems), which has been confirmed in numerous studies [5].

As with defoliation, six years of monitoring and assessing discolouration is a period too short to form a reliable trend in the variation of this phenomenon. However, it can be concluded that in this period of time, beech forests on the analyzed sample plots had a consistent percentage of trees unaffected by discolouration.
The data that represent damage are in function of the first two parameters of health state (defoliation and discolouration). Defoliation and discolouration depend on damage and the three parameters are interdependent.

The trend extrapolated after processing the data on the damage inflicted in this period of time was reliable (a regular pattern of development). In other words, beech forests showed a decreasing frequency of damage in the period of observation and monitoring. The influence of damaging agents is presented in Table 5.

Beech forests showed a slightly more pronounced defoliation in 2008 (84.0\% of trees showed no signs of defoliation in comparison with 2009 when $96.7 \%$ of trees were not affected by defoliation) [6]. The percentage of trees with no signs of discolouration was constantly high at the time of observation. Discolouration was not registered in more than $90 \%$ of trees. The frequency of damage was steadily decreasing in this period and the values ranged approximate as is the case for defoliation and discolouration. The frequency of damage on beech trees in this period was quite uniform.

\section{DISCUSSION AND CONCLUSIONS}

Pathogenic fungi and destructive insects are organisms that accompany certain natural ecosystems.

TABLE 5

Causes of damage on beech trees in Serbia in the period 2004-2009

\begin{tabular}{|c|c|c|c|c|c|c|c|}
\hline \multirow{3}{*}{ Year } & \multicolumn{7}{|c|}{ Agent } \\
\hline & Insects & Fungi & Abiotic & Human & Fire & No damage & $\begin{array}{c}\text { Other } \\
\text { damage }\end{array}$ \\
\hline & \multicolumn{7}{|c|}{ (\%) } \\
\hline 2004 & 20.3 & 3.9 & 1.3 & 1.2 & 0 & 84.0 & 1.5 \\
\hline 2005 & 27.4 & 2.8 & 0 & 0.1 & 0 & 87.8 & 0 \\
\hline 2006 & 30.2 & 16.2 & 11.1 & 3.4 & 0 & 93.4 & 1.2 \\
\hline 2007 & 24.7 & 11.5 & 6.6 & 2.4 & 0 & 90.2 & 0.1 \\
\hline 2008 & 11.4 & 9.2 & 3.3 & 1.5 & 0.5 & 92.8 & 2.7 \\
\hline 2009 & 7.2 & 8.7 & 0 & 0 & 0 & 96.3 & 8.0 \\
\hline
\end{tabular}


Because of their destructive activities, one of the objectives of forest management is to control insect populations and to reduce their status to a tolerable level or to a number which cannot cause extensive damage [7].

Collecting these data over a longer period of time and relating them with the stand characteristics will give us a deeper insight into the reasons for forest deterioration both in time and in space.

The sample beech trees were the most vital in the final year of research (2009), which can be both in the case of defoliation and in the case of discolouration explained by favourable hydro-meteorological conditions (temperature and precipitation within the boundaries, without extremes).

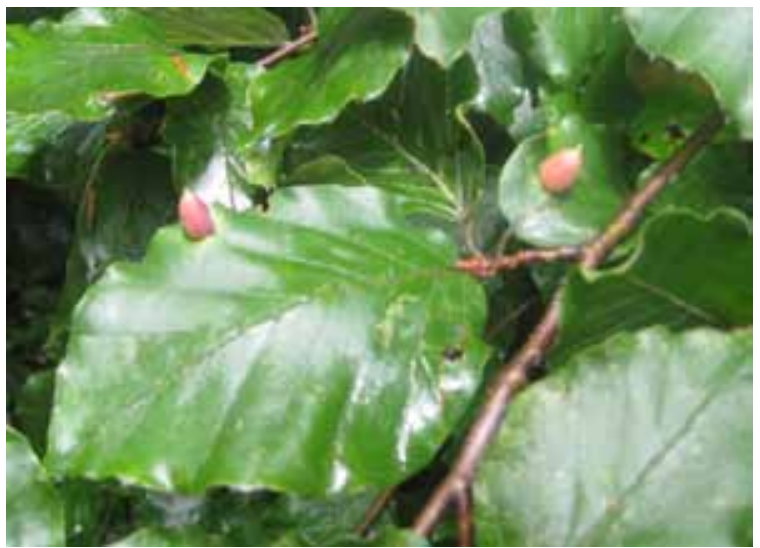

FIGURE 1

Galls caused by Mikiola fagi

The present condition of beech forests, both coppice and high, in Serbia is unfavourable. They are degraded, their quality is unsatisfactory, as well as their health condition. It is well known that despite its good technical properties, beech wood is vulnerable and susceptible to the attack of various parasitic and saprophytic organisms. Their activities make physiologically weakened and diseased trees an easy target for the attack of various primary and secondary harmful insect species, which can ultimately lead to deterioration of both individual trees and groups of trees [7].

Approximately 150 species of insects were found and registered on beech trees. They live, grow and feed on different parts of beech trees [8]. Only a small number of them is characteristic only of beech, while the majority can live on other tree species. There are three main groups of insects, depending on the tree part they feed on: I) the insects that suck up plant sap from the foliage and branches, II) the insects that feed on foliage tissue, either on the surface or hidden in the tunnels and galls and III) the insects that live and feed on wood [8]. The first group is represented by the widely-spread Phyllaphis fagi L..

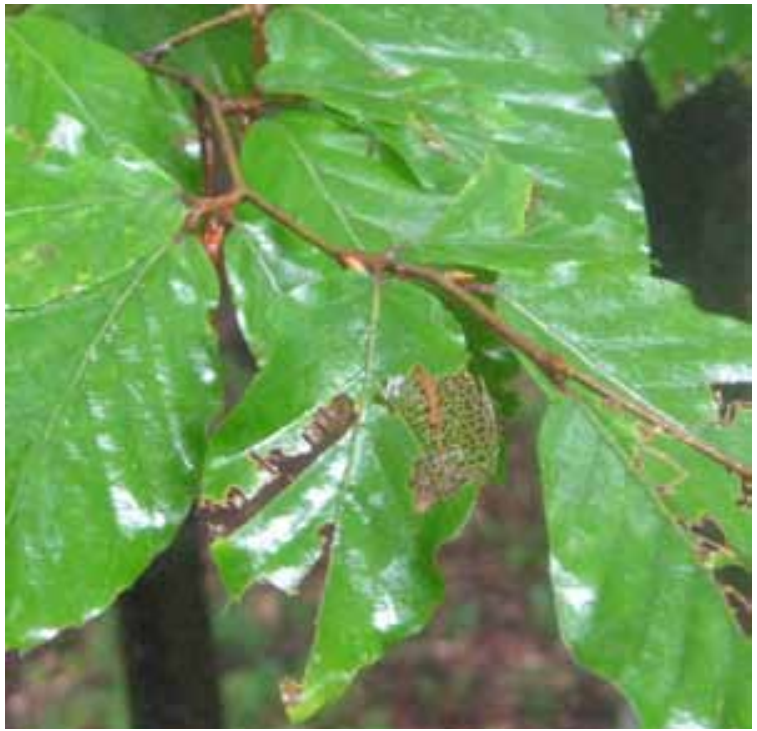

FIGURE 2

Damage - Orchestes fagi

The damage to beech leaves caused by insects is mainly by mining and gall making insects. Mikiola fagi (Htg.), (Figure 1) makes galls on beech leaves which then become deformed while their assimilation capacity becomes reduced. Rhynchaenus fagi $\mathrm{L}$. (Syn. Orchestes fagi L.), (Figure 2) or the beech weevil causes damage only in mature beech trees. It reduces the assimilation leaf area and causes physiological weakness of the attacked trees. Furthermore, trees on sample plot 87 suffered considerable damage caused by beech aphids Phyllaphis fagi L. (Figure 3), at the time of their swarming.

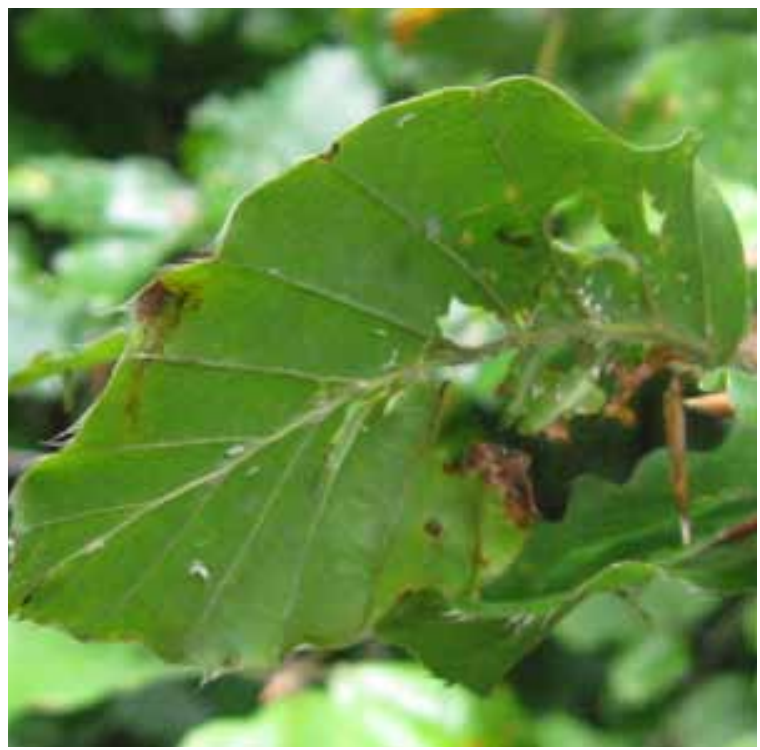

FIGURE 3

Beech aphids Phyllaphis fagi 
Fruiting bodies of the wood-rotting fungus Laetiporus sulphureus (Fr.) Murrill (Figure 6) occur on some beech tree trunks. There are some canker-infested areas on the bark and the tree butts are slightly affected by the presence of several different wood-rotting fungi, but only to a smaller extent.

A great number of fruiting bodies of Fomes fomentarius (L.: Fr.), (Syn. Ungulina fomentaria/Linn./Pat) (Figure 4) was found on the branch litter as well as a small number of Nectria sp.

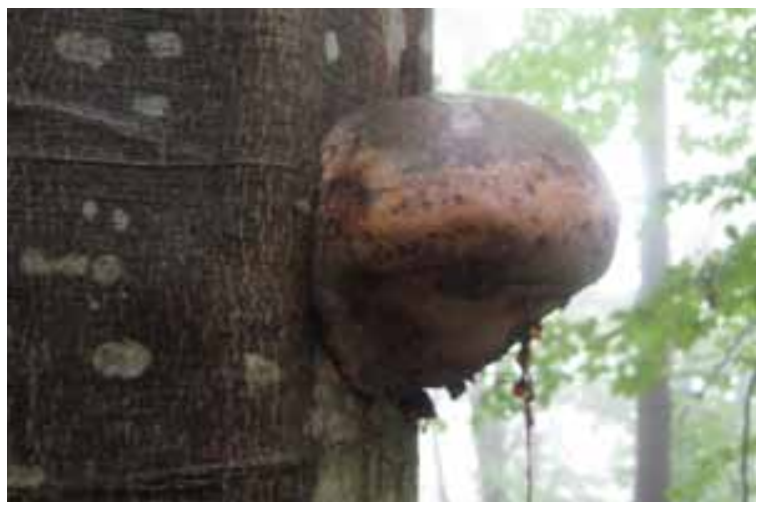

\section{FIGURE 4}

Fomes fomentarius on beech trunk

There is also a great number of decayed trees attacked by wood-rotting fungus Trametes versicolor (Fr.) Pil. (Syn. Coriolus versicolor L. Et Fr.) Quel.) in the vicinity of beech sample plots [9].

Gnarls of non-parasitic origin are the most common type of abiotically caused damage. They appear on the bark of the beech tree trunks and their size can be from a few millimeters up to three centimeters in diameter. They are present in large numbers on individual trees. The greatest extent of mechanically caused damage to young beech trees in this period was done by hail. Frost injured young leaves are a very frequent occurrence too (Figure 5).

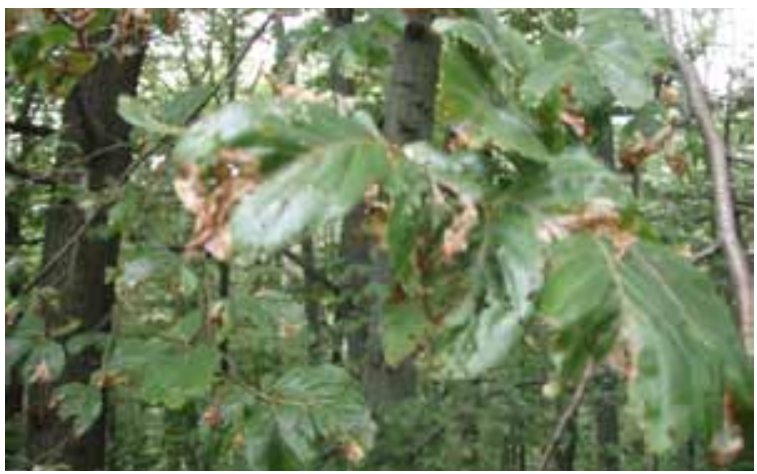

FIGURE 5

Frost damage
As the most common tree species in our country, beech is still in a good state of health. However, the above stated damaging agents have threatened its existence in certain localities and made it predisposed to future outbreaks of harmful pests and diseases [10]. Dying or deterioration of beech forests is the result of adverse effects of different abiotic and biotic factors on trees as living organisms and on complex natural processes within forest ecosystems. The agents that belong to one of these two groups (biotic and abiotic) can act either simultaneously or in succession. In order to determine the processes of forest ecosystems decaying, it is necessary to do detailed research of ecological and socio-economic consequences of forest deterioration and to analyze the impact of regional climate changes on beech forest communities.

The assessment of the crown condition, through defoliation and discolouration, as well as the estimation of the damage inflicted to trees by various diseases and pests on the established sample plots in the period from 2004 to 2009 make a notable contribution towards reaching final conclusions about the adverse effects of different biotic and abiotic factors on the vitality of beech forests in Serbia, in the region and throughout Europe [10].

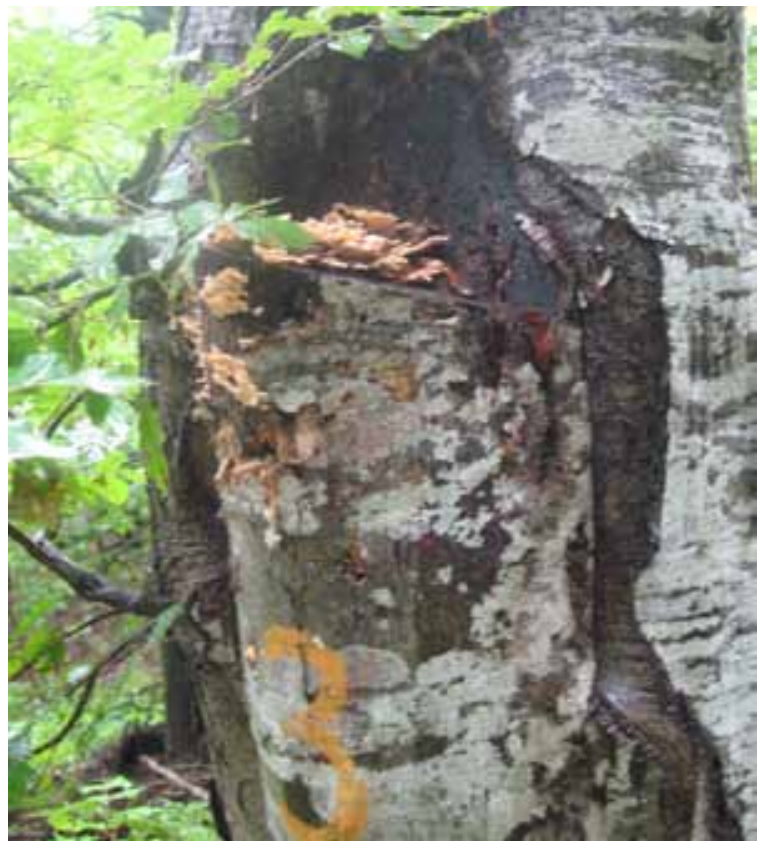

FIGURE 6

Laetiporus sulphureus on marked beech

The impact of pollution and climate change on the forest vitality is an apparent phenomenon in Serbia, in the whole region and throughout Europe. It poses pressing issue which has to be addressed both in our country and worldwide. 


\section{REFERENCES}

1. Fourth Ministerial Conference On the Protection of Forests in Europe (MCPFE) 2003 Conference Proceedings, Vienna, Austria, p 211-222

2. UN EC ICP Forests 2010 Manual on methods and criteria for harmonized sampling, assessment, monitoring and analysis of the effects of air pollution on forests, Part I Mandate of ICP Forests and Programme Implementation, updated: $05 / 2010$

3. UN EC ICP Forests 2010 Manual on methods and criteria for harmonized sampling, assessment, monitoring and analysis of the effects of air pollution on forests, Part IV -Visual Assessment of Crown Condition and Damaging Agents, updated: 05/2010. Available at: http://www. icp-forests.org/pdf/FINAL_Crown.pdf

4. UN EC ICP Forests 2010 Manual on methods and criteria for harmonized sampling, assessment, monitoring and analysis of the effects of air pollution on forests, Part II -Basic design principles for the ICP Forests Monitoring Networks, ICP Forests, 2010, updated: 05/2010. Available at: http://www.icp-forests.org/pdf/FINAL_part2.pdf

5. DE VRIES W, BAKKER D J 1998 Manual for calculating critical loads of heavy metals for terestial ecosystems. Guidelines for critical limits, calculation methods and input data, Wageningen, DLO, Winand Staring Centre, Report 166, p 144
6. NEVENIĆ $R$ et al 2010 Praćenje i procena uticaja zagađenja vazduha i njegovih efekata u šumskim ekosistemima na teritoriji Republike Srbije. NFC Srbije Nacionalni fokal centar Srbije, Godišnji izveštaj za 2009, Institut za šumarstvo. Monitoring and Impact Assessment of Air Pollution and its Effects in Forest Ecosystems on the Territory of the Republic of Serbia. NFC Serbia - National Focal Center Serbia, Annual Report for 2009, Institute of forestry, Belgrade, p 1-220

7. TABAKOVIĆ - TOŠIĆ M, MARKOVIĆ M, 2004 The influence of phytophagous insects on the health status of coppice beech forests of eastern Serbia. Collected Works, Collection Tom 50-51, Institute of Forestry, Belgrade, p 56

8. MIHAJLOVIĆ U 2008 Forest Entomology. Textbook Faculty of Forestry, Belgrade, ISBN 978-86-7299-152-9, p 499

9. KARADŽIĆ D 2010 Forest Phytopathology. Textbook, Faculty of Forestry, Belgrade Faculty of Forestry, Banja Luka, ISBN 978-86-7299-177-2, p 330

10. NEVENIĆ R, TABAKOVIĆ - TOŠIĆ M, RAKONJAC U, 2009 Some indicators of the vitality of forests of the Republic of Serbia 2004-2008. Monographs, Institute of Forestry, Belgrade, ISBN 978-86-80439-18-1. UDC 630th p 1-134 